\title{
COMMENTATIONES
}

\author{
KRYSTYNA BARTOL \\ Uniwersytet im. Adama Mickiewicza w Poznaniu
}

\section{WAS CALYPSO ABLE TO MAKE ODYSSEUS IMMORTAL?}

\begin{abstract}
Bartol Krystyna, Was Calypso Able to Make Odysseus Immortal? (Czy Kalipso mogła uczynić
\end{abstract} Odyseusza nieśmiertelnym?)

The article, focusing primarily on the Odyssey 5. 135-6, offers a set of remarks designed to foreground the qualities that make the Calypso episode not only interesting as an example of how the epic poet exploits traditional themes and phrases, but exciting as a story of a man's desire.

Keywords: Greek epic poetry; the Odyssey; Calypso; Odysseus; immortality.

... You give the choice To hold forever what forever passes, To hide from what will pass, forever.

Archibald MacLeish, Calypso's Island, vv. 28-30 (Collected Poems 1917-1952, Boston 1952, p. 147)

The natural order of things is that death is common to all men. Homeric poetry knows this important share of men. ${ }^{1}$ It is enough to recall some passages from both poems which echo the universal fate of death, the rule that should not be upset. In the Iliad (16. 440-3) Hera disbelievingly asks Zeus if he really wants to free Sarpedon from death, a mortal man, and warns him not to set a precedent. Also in the Iliad (22.178-81) Athena is indignant at Zeus' intention

${ }^{1}$ As Claude Brügger $(2016,204)$ points out in the recent volume of the Basler Kommentar: "Die Sterblichkeit ist eine Grundlage menschlichen Daseins, selbst wenn ein Held wie Sarpedon, Askalaphos oder Achilleus eine Gottheit als Elternteil hat (...): er wird früher oder später sterben müssen". See also Redfield's $(1994,101)$ words referring to Homeric heroes' status: "The hero may appear godlike, but he is only mortal. (...) Man dies in any case, but he can choose to die well. (...) All men are born to die, but the warrior alone must confront this fact in his social life, since he fulfills his obligations only by meeting those who intend his death". 
to save Sarpedon and Hector from death: "What a thing have you said. A mortal man, doomed long since by fate, are you minded to free from dolorous death? Do it, but be sure we other gods do not all assent to it."2 The Odyssey (3. 2368) has a strikingly similar passage about the gods' protective attempts towards mortals: "But clearly death that is common to all not even the gods themselves can ward off even from a man they love, whenever the fell fate of pitiless death strikes him down." ${ }^{3}$

The corpus of surviving Greek epics provides us, however, with remarkable cases of the gods making some exceptions for certain mortals. ${ }^{4}$ Moreover, the immortalization of a man by gods is not only associated with the stories about armed conflict - as it is in the case of Memnon who, after being killed, was abducted and translated from the battlefield, ${ }^{5}$ or that of Achilles who was snatched up from the funeral pyre and brought to the Isles of the Blessed ${ }^{6}$ (both were immortalized by the intervention of their divine mothers $)^{7}-$ but gods also wanted to confer immortality on those mortals whom they fell in love with and whom they took as his/her own bedfellows (as it was in the case of Tithonus' affair with $\operatorname{Eos}^{8}$ or Ganymede's abduction by Zeus). ${ }^{9}$ Of course early poetic pieces bring also other stories or mentions dealing with a mortal getting a form of immortality from a god or with gods' attempts to make a man immortal, in which the divine help with men's transcending his/her mortality was motivated in various ways: from Proclus' summary of the Cypria we know that Artemis snatches away Iphigenia, whom Agamemnon wanted to sacrifice in Aulis, and made her immortal. ${ }^{10}$ The Hesiodic fragment (19. 201ff. Most. = 23a. $21 \mathrm{ff}$. M.-W.) gives more details about the act itself. We read: "and lovely ambrosia she [Artemis] dripped onto her [Iphigenia's] head, so that her flesh would be

${ }^{2}$ Transl. Murray 2001, 465.

${ }^{3}$ Transl. Murray 1998, 97.

${ }^{4}$ See Griffin 1997, 42: "The cycle (...) admits miracles of a sort which Homer does not. In relation to the most basic conditions of human life", Davies $(1989,59)$, who compares Homeric poems with the epic cycle: "In each case the contrast with the austerity of Homeric poems, where even the greatest heroes must die (...) is immense". See also Finkelberg 2015, 133: "in both Hesiod and the Cycle the heroes' immortalization seems to be the norm."

${ }^{5}$ See the argumentum of the Aethiopis in Proclus' Chrestomathy (3e). For the comments on this theme in the cyclic poem see West 2013, 148-9.

${ }^{6}$ See Proclus' summary of the Aethiopis (4b) and West's (2013, 155-6) comment on it.

${ }^{7}$ For other well-recognized similarities between both immortalizations see Davies $(1989,55)$. See also Kullmann's remarks on some parallels between the Memnon story in the Achilleis and the Iliad (Kullmann 2015, 113-119).

${ }^{8}$ The story is told by the author of the Hymn to Aphrodite (v. 218-38). For the useful survey of ancient testimonies referring to the story see Richardson 2010, 247-8.

${ }^{9}$ See Il. 20. 232-5, Hymn.Ven. 202-17 with Faulkner's (2008, 263-9), and Richardson's (2010, 246-7), commentaries.

${ }^{10} \mathrm{Arg} .8$. 
steadfast forever and she made her immortal and ageless all her days." ${ }^{11}$ In the cyclic Thebaid Athena, as we are informed by the scholiast on the Iliad (Schol. (D), Il. 5.126), ${ }^{12}$ was bringing Tydeus, the son of Oineus, immortality, but when she saw his horrible behaviour in the Theban war (he split open the head of the killed Melanippus and gobbled the brain in a passion) she turned away from him, but did agree to bestow immortality on Diomedes, Tydeus' son. There are of course other examples of mortals being immortalized in early Greek poetry, but I am not going to enumerate all of these numerous stories. ${ }^{13}$ Let us only say that all these instances of mortals' immortality should be regarded, as Martin West rightly pointed out, as the poetic or honorary type "with no reality in cult." 14

Although the idea of crossing the fundamental opposition between gods and humans must have been attractive in itself to the first audiences of epic songs, the erotic implications of such stories seem to appeal in a particular way to the public with their absorbing narratives, ${ }^{15}$ exquisite emotional characterizations and the striking timelessness of the problem. ${ }^{16}$

As it is commonly known, the greater part of the fifth Book of the Odyssey is concerned with such a story. ${ }^{17}$ Its heroes, Calypso, the beautiful goddess, and Odysseus trapped with her for seven years ${ }^{18}$ on Ogygia, the island, a kind of idyllic Alcatraz, as Martin West imaginatively called the place, ${ }^{19}$ share a bed in

${ }^{11}$ Transl. Most 2007, 69-71.

${ }^{12}$ Fr. 9 Bernabé ( $=9$ West).

${ }^{13}$ For more examples see Griffin 1977, 42-3.

${ }^{14}$ West 2013, 149.

${ }^{15}$ See West 2014, 127-9.

${ }^{16}$ The attention paid by the scholiasts on the Odyssey, and other ancient interpreters of Calypso's promise of immortality to Odysseus, testifies to the liveliness of this theme. For a study of this ancient material see Pontani (2013).

${ }^{17}$ The message of the story was seen moving by many readers at all times. Let me only mention the words from Oscar Wilde's earliest surviving prose work, The Women of Homer (an article surveying the chapter The Women of Homer from J.A. Symonds' Studies of the Greek Poets), which capture readers' interest in it: "I have dwelt thus long on Calypso, because there seems to me to be extreme pathos in the story. Her love is not that of Circe which turns men into brute beasts, nor yet is it a love which satisfies: rather is it a love which keeps men from the toil and struggle of life yet gives them happiness after all" (Wright, Mead 2011, 79).

${ }^{18}$ Some scholars say that years of Odysseus' sojourn with Calypso are of no importance for the characterization of the hero. They argue that they simply explain the absence of hero, as in other traditional stories of the Return of the Husband. See Alden $(1985,106)$, who says: "the returning hero has very often simply been delayed by unwanted hospitality or imprisonment". See also Hainsworth $(1998,249)$, who argues that Calypso "contributes more to the structure than to the substance of Odyssey", thereby treats Odysseus' detention by Calypso necessary "till the twentieth year from his departure to Troy" (Hainsworth 1998, 249). But see Güntert 1919, 20: "unsere Odyssee ohne Kalypso undenkbar ist", since "Kalypsoabenteuer" is "Höhepunkt der Prüfungen des Helden" (Güntert 1919, 16). See also Finley $(1978,77)$ who ingeniously notes: "The quiet of his seven years $(\ldots)$ conveys his half-entrance into timelessness."

${ }^{19}$ West 2014, 128. 
her hollow caves, but do not share their deepest desires: she wishes him to be her husband, he is filled with longing for his return and for his wife. Calypso's expectations from Odysseus and Odysseus' displeasure at the goddess' love are mentioned for the first time by the narrator just after the proem in Book One (1. 13-15). So the situation on Ogygia is not new ${ }^{20}$ to the narratees when they learn from Athena's speech at the beginning of Book $5(13-15)^{21}$ that "he lies in an island suffering grievous pains, in the halls of the nymph Calypso, who keeps him perforce, and he cannot return to his own land." 22 A new important detail regarding the story does not appear until Calypso speaks. When she addresses Hermes who came to announce Zeus' will to her she says (Od. 5. 135-6):

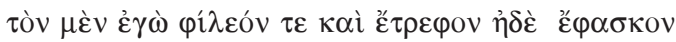

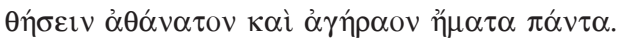

(Him I welcomed kindly, and gave him food, and said that I would make him immortal and ageless $^{23}$ all his days. $)^{24}$

Later, in the scene of her encounter with Odysseus, she refers again to her offer of immortality saying the following to Odysseus (Od. 5. 206-9):

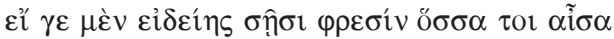

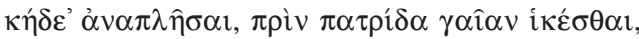

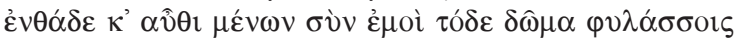

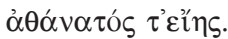

(If, however, in your heart you knew all the measure of woe it is your fate to fulfill before you come to your native land, you would remain here and keep this house with me, and would be immortal. $)^{25}$

The reference to her offer will be mentioned twice more by Odysseus himself ${ }^{26}$ (Od. 7. 256-7 and 23. 335-6), but to both of these places I will return in a moment.

${ }^{20}$ The recurrence of the motif of Calypso is of great importance for the structure of the Odyssey. Cf. Thornton 1970, 126: "The recurrent motif of Calypso, the 'Concealer' of Odysseus, permeates the first half of the Odyssey. She is also the last of his adventures before his arrival in Phaeacia, and in a way she is the culmination and epitome of all his adventures because in each one he is either threatened by death or tempted to stay."

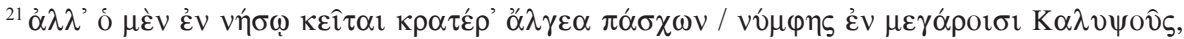

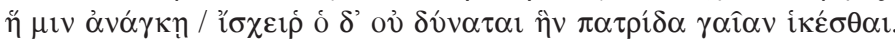

${ }^{22}$ Transl. Murray 1998, 183.

${ }^{23}$ On this epic formula against the background of the Indo-European tradition cf. West 2007, 128.

${ }^{24}$ Transl. Murray 1998, 193.

${ }^{25}$ Transl. Murray 1998, 197.

${ }^{26}$ Both Odysseus' narratives are mirror-stories, i.e. they report events that have already been narrated. See de Jong 2001, 184. 
Was Calypso able to make Odysseus immortal? ${ }^{27}$ If so, why did she wait seven years of keeping him on her wildly serene island and letting him remain on the mortal side? ${ }^{28}$ Why did not she feed him on nectar and ambrosia, which was a simple way - besides anointing a man with something divine ${ }^{29}$ - of making a mortal immortal $?^{30}$ In the scene between Calypso and Odysseus (Od. 5. 194-9) the distinction between her divine and his human natures is carefully marked:

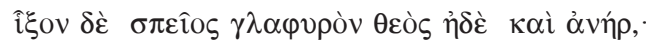

$(\ldots$

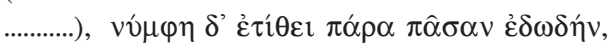

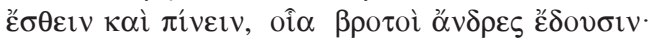

$\alpha$

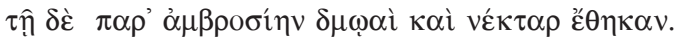

(As they came to the hollow cave, the goddess and the man, (...) the nymph set before him all kinds of food to eat and drink, of such sort as mortal men eat. (...) before her the handmaids set ambrosia and nectar. $)^{31}$

What prevented her from serving Odysseus with the food that the gods consume? What did she need to fulfill her dream? Zeus' approval? Or perhaps Odysseus' consent? Both being unattainable.

Although scholars today dispute whether gods could make a mortal immortal only by imploring Zeus, ${ }^{32}$ or whether they could do it on their own initiative, ${ }^{33}$ in the case of our poem it seems that Zeus' approval or Zeus' refusal is totally unimportant since "it is his [i.e. Odysseus'] fate to see his own people, and reach his high-roofed house and his native land" ${ }^{34}$ (Od. 5. 41-2,,$^{35}$ additional

${ }^{27}$ The answer to the question which I put in the title of this article seems also - although indirectly - to give the answer to the question asked by Pontani $(2013,31)$ : "My first question asks whether or not Calypso is actually in love with Odysseus".

${ }^{28}$ See Walcot's $(1991,151)$ answer to his questions: "Calypso informs Hermes that she has looked after Odysseus and told him that she would make him immortal and ageless (...), but she has certainly not fulfilled so generous a promise as yet; the 'casualness' with which we learn of the offer suggests that this is not a serious proposition but an extravagant statement made by a clearly infuriated female".

${ }^{29}$ As in Hes. fr. 19. 21 ff. Most = fr. 23(a), 21ff. M.-W. See Hainsworth 1988, 268.

${ }^{30}$ On the immortal nature of nectar and ambrosia see Pulleyn 2006, 61-74. See also Currie 2016, 65-6.

${ }^{31}$ Transl. Murray 1998, 197.

${ }^{32}$ As assumed by Walcot $1991,150-1$.

${ }^{33}$ As Currie argued (2016, 180, n. 189): "There is no reason to suppose that deities could not make mortals immortal on their own initiative. (...) Eos' appeal to Zeus for Memnon's immortality (...) does not have the status of a rule."

${ }^{34}$ Transl. Murray 1988, 185.

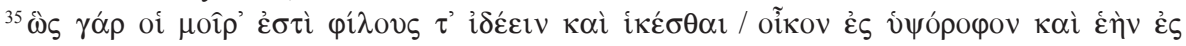
$\pi \alpha \tau \hat{i}^{\delta} \delta \alpha \gamma \alpha \hat{\imath} \alpha \nu$. 
explanation at $\mathrm{Od}$. 5.113"36: "for it is not his fate to perish here far from his friends." $)^{37}$ The power of moira, i.e. of what is allotted to one, especially the destiny of human death, seems in the case of some persons irreversible, even for Zeus. Moreover, Calypso knows that her possible appeal to Zeus for Odysseus' immortality would encounter strong resistance, since, in her opinion, it was him - not Athena, as Hermes says (Od. 5. 108-9) - who caused the disaster of homecoming warriors after having sacked the city of Priam, and it is him who "had struck Odysseus' swift ship with his bright thunderbolt and had shattered it in the midst of the wine-dark sea" ${ }^{38}$ (Od. 5. 128-9). ${ }^{39}$ One may think that Calypso by defining Zeus as the Verursacher der Katastrophe - as Danek cleverly points out ${ }^{40}$ - suggests that now too he is planning to give Odysseus again hell on earth making him wander and suffer anew. To do so he must make him leave Calypso's apparent paradise. ${ }^{41}$ Moreover, she interprets Zeus' order to let Odysseus go his way as the cruel punishment of the jealous god, inflicted on her because of her having slept with a mortal. ${ }^{42}$

It is not pointless to ask whether Calypso could make Odysseus immortal without his consent. Generally it seems that the gods did not care about the mortals' permission: Zeus seized Ganymede because of his beauty making him "immortal and unaging just like gods"43 (Hym.Ven. 214) ${ }^{44}$ Eos seized Tithonus and asked Zeus to make him "immortal and living for ever" 45 (Hym.Ven. 221). ${ }^{46}$ We know, however, nothing about their willingness or consent. From the text of the Homeric Hymn to Aphrodite one can suppose that it is a god's, not a mortal's wish which

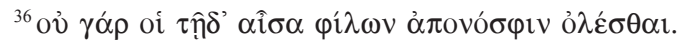

${ }^{37}$ Transl. Murray 1998, 191.

${ }^{38}$ Transl. Murray 1998, 191, 193.

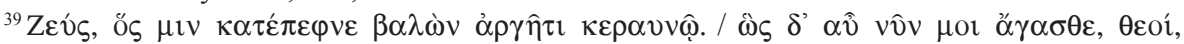

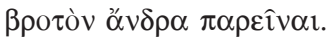

${ }^{40}$ Danek 1988, 127.

${ }^{41}$ The similarities between Ogygia and Elysium have been explored by Anderson (1958, 7): "Like Elysium (...) Ogygia can confer upon Odysseus immortality, with all that the term connotates of security and sensuous ease," and (Anderson 1958, 7): "In the case of Calypso's Island, the immortality offered to Odysseus contains many suggestions not of eternal life, but of eternal death. (...) Odysseus begins his human life again by escaping from that oblivious ease offered him by Calypso, the one who buries."

${ }^{42}$ For the problem of interpretation of Calypso's speech (5. 118-36) and the ambiguity of her choice of stories see Sammons 2010, 43-4. See also Scodel $(2009,146)$, who points out: "The examples are slightly "off", since the mortals in them die because the gods want to separate them from their goddess-lovers, while Odysseus is "dead" on Calypso's island and returns to life by leaving her."

${ }^{43}$ Transl. West 2003, 175.

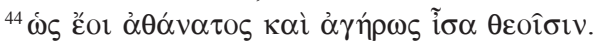

${ }^{45}$ Transl. West 2003, 177.

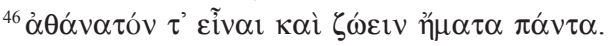


matters in such situations (Hymn.Ven. 239-40) ${ }^{47}$ : "I would not choose for you to be like that among the gods, to be immortal and live for ever," ${ }^{, 48}$ replies the goddess to Anchises (Hymn.Ven. 188-949: "do not leave me to dwell among mankind," 50 which some scholars understand as a request for immortality. ${ }^{51}$ Calypso's case appears to be different. She seems to need his positive answer to her proposal of eternal life and youth because it will be understood by her as the declaration of his reciprocity. ${ }^{52}$ And this is what she was dreaming of in vain for the last seven years. ${ }^{53}$ Without his positive answer her love for him remains unrequited. Perhaps Calypso's promise to remove mortality from Odysseus must be treated only as a kind of her desperate call for his reciprocity. ${ }^{54}$ Although she knows that she is not capable of granting such a gift, she is trying to delude him into believing that she is able to do it hic et nunc. When after Hermes' departure, during the conversation with Odysseus on the shore she declares (calling Earth, Heaven and Styx) that she "will not plot against him any fresh mischief"55 (Od. 5. 187) $)^{56}$, she may have in mind her delusive offer repeated by her over and over again for seven years. It seems that also the verb है $\varphi \alpha \sigma \kappa o v$, carrying strongly iterative force here, which she herself uses to describe what she was doing towards Odysseus: $\tau$ òv

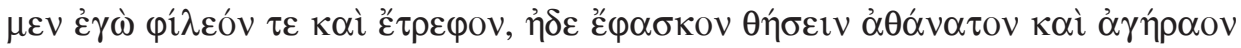
$\eta \mu \mu \alpha \tau \pi \alpha \alpha^{\prime} \tau \alpha$ ("Him I welcomed kindly, and gave him food, and said that I would make him immortal and ageless all his days") may be best taken to suggest this hollowness of her words. She knew that she was unable to make him immortal. But did Odysseus know that her offer was unrealistic? Modern commentators want to believe that he did not. If so, his choice, ${ }^{57}$ i.e. forgoing immortality, makes him even more heroic against Achilleus' heroism, that is, his rejection of a long

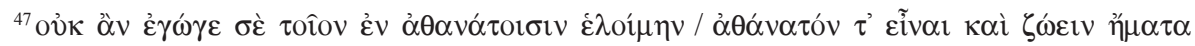
$\pi \alpha ́ v \tau \alpha$.

${ }^{48}$ Transl. West 2003, 177.

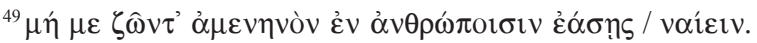

${ }^{50}$ Transl. West 2003, 173,175.

${ }^{51}$ On various interpretations of this passage see Faulkner 2008, 251.

${ }^{52}$ It is perhaps worth mentioning in this place Calypso's words addressed to Odysseus in Pascoli's poem Il ritorno, a part of his Monodia di Odisseo, composed in 1896. At 142-3 we read: "Mi disse: Immortale / sarai, se rimani ...". On the problem of the reception of the affair with Calypso in Pascoli see Mitro (2008, 6-14).

${ }^{53}$ Finley $(1978,79)$ stresses "the simplicity of her reliance on her love and beauty."

${ }^{54}$ She feels, as Sammons $(2010,40)$ suggests, that her love endangers her dignity, but she tries to rescue it "by putting her case in parallel with the sufferings of other goddesses".

${ }^{55}$ Transl. Murray 1998, 195.

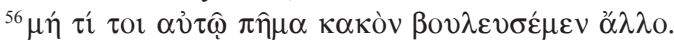

${ }^{57}$ But see the 'unromantic' Buchnan's reading of Odysseus' choice, Buchnan $(2004,8)$, who says: "He may be less interested in the apparent absence of the supposed object of the journey, Penelope, and more afraid of losing the desire for a return," and who sees Odysseus "as trapped between two women. They threaten him precisely because they offer to satisfy his desire."
} 
life, as Bruno Currie has recently pointed out. ${ }^{58}$ If so, Odysseus' choice may be also treated as the early example of human liberation from god's will and a proof of a mortal's free will, as Dieter Lohmann argued in 1990s. ${ }^{59}$ Or perhaps it is these scholars who see in the objective narrative of Odysseus' return to Ithaca (Od. 5-13) a repetition (with some modifications) of the plot from Gilgamesh's quest for immortality that are in the right. In the Akkadian epic the hero fails to attain eternal life and agelessness, in the Odyssey the hero declined both, ${ }^{60}$ which means that he remained mortal and aging. ${ }^{61}$ One should also remember Vernant's diagnosis: "Sharing divine immortality in the nymph's arms would constitute for Odysseus a renunciation of his career as an epic hero." ${ }^{\circ 2}$

One may ask at which moment of his seven-year stay on Ogygia Odysseus guesses (if ever) that Calypso's offer is an illusion. From his own story told on Scheria we learn that he was aware of Hermes' visit to Calypso (Od. 12.389-90), although she said nothing of his visit when she found Odysseus on the shore and announced that she was going to send him home. ${ }^{63}$ Perhaps two phrases spoken by

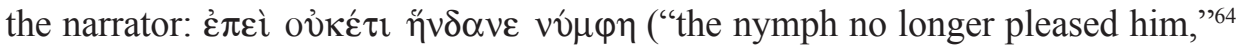

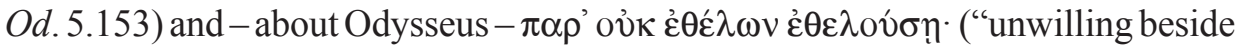
the willing nymph," ${ }^{65} \mathrm{Od}$. 5.155) suggest that there must have been a moment

${ }^{58}$ Currie 2016, 46, n. 46. For interesting remarks on Achilleus' and Odysseus' choices see Rutherford (1991-3), 47 (reprinted in Cairns 2001, 133). On this subject see also Crane 1988, 15: "Ogygia was for Odysseus as much as island of the Blessed, as Leuke was for Achilles - or it would have been, had Odysseus chosen to stay. Ogygia is far more complex than any of its analogues, its charm not without cost and its promise ambiguous, but every shadow or equivocating detail turns upon a single principle. When Odysseus turns aside the offer of immortality, he also turns aside from the path that any other hero would have followed."

${ }^{59}$ D. Lohmann 1998, 40: "dieses Hohelied menschlicher Willensfreiheit".

${ }^{60}$ See Güntert 1919, 156, emotional remark: "Was Odysseus verschmäht, ist später des Mysten höchster Wünsch. So steht auf einer lamina aurea aus dem 4 vorchristl. Jahrh."

${ }^{61}$ For the comparison between Gilgamesh story and Odysseus' adventures see West 1997, 41-12, 422-8 and Kozłowski 2015.

${ }^{62}$ Vernant 1996, 188. See also 189: "It is for those reasons, then, that Odysseus rejects his immortality granted by a woman's favor; by removing him from what constitutes his life, it leads him at last to find death desirable." On the other hand, Vernant and other scholars who see the Odyssey as the product of the multi-version heroic tradition, in which one finds the episodes placed within a framework of commonly known mythical epic stories, pay considerable attention also to the problem of the singer's or story-teller's reference to the listeners' familiarity with the plots of epic stories and the public's expectations. As a perfect illustration of this position G. Nagy's book (2010), and K. Zieliński's monograph (2014), can be used. I am grateful to the anonymous referee for pointing out the importance of the issue that this paper does not tackle. Yet I hope it may make a contribution to the question of how Calypso episode can be interpreted.

${ }^{63}$ Aristarchus rejected the whole of $12.374-90$ as interpolation. On the lack of reference to Hermes' visit in the conversation between Calypso and Odysseus in Book 5 as the reason of the Alexandrian critics' decision see Heubeck 1989, 139.

${ }^{64}$ Transl. Murray 1998, 193.

${ }^{65}$ Transl. Murray 1998, 193. 
when Odysseus changed his attitude towards his beautiful mistress living on the island at the Navel of the Earth. But it remains unclear if he believed in Calypso's offer when still being "willing" and when the nymph still pleased him. I doubt it.

Independently of whether Odysseus believed in Calypso' words on Ogygia or not, it is clear that his later accounts of his adventures on Calypso's island are constructed by him in such a way that he appears - in the eyes of his audience to be a man who truly resisted the temptation to be immortal and forever young. Although his narratives addressed to Arete while staying with the Phaecians (Book 7. 255-7) and to Penelope on Ithaca (Book 23. 335-6) include the partly verbatim repetitions of Calypso's words, they serve a particular purpose in relation to the self-presentation of Odysseus: they are intended to present him as a man who had immortality at his fingertips and resisted the temptation because there were other loves which mattered more to him than the deceptive happiness and eternal life with Calypso, such as his wife, Ithaka or the wanderings themselves. ${ }^{66}$ Chris Pelling in his compelling essay on Homer ${ }^{67}$ rightly stressed that Odysseus is very good at finding the right things to say to a woman. I agree that he is. It is not a pure coincidence, as it seems, that Odysseus, just before feeling that he may be tempted to stay on Scheria as Alcinouos' son-in-law, says (Od. 7. 256-9):

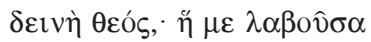

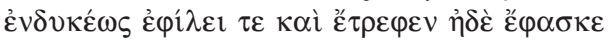

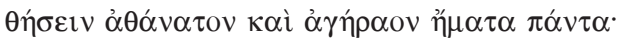

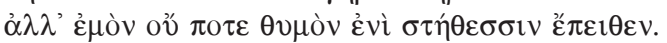

(a dread goddess. She took me to her home with kindly welcome, and gave me food, and said she would make me immortal and ageless all my days, but she could never persuade the heart in my breast. $)^{68}$

He manipulates then the story ${ }^{69}$ stressing his resistance in order to show he would not be interested in a royal (but mortal) daughter. ${ }^{70}$ The same happens

${ }^{66}$ It is tempting to recall Cavafy's words from the beginning of his poem: "As you set out for Ithaka / hope your road is a long one, full of adventures, full of discovery" (transl. Keeley and Sherrard in Cavafy 1992, 36).

${ }^{67}$ Pelling 2014, 15.

${ }^{68}$ Transl. Murray 1998, 265.

${ }^{69}$ See de Jong 2001, 184-5: "While the information Odysseus provides is new to Arete and Alcinous it is not new to the narratees; for the latter, this passage is interesting above all for the correspondences and differences between the earlier version and Odysseus' account. The correspondences are partly verbatim (...); these verbatim repetitions indicate the points where Odysseus shares the focalization of Calypso and the narrator. The differences are due largely to three function: Odysseus' (I) subjective focalization (he is the one who underwent the events recounted), (II) restricted knowledge (as opposed to the omniscience of the narrator), and (III) rhetoric (his narrative is intended to dispel Arete's suspicions)."

${ }^{70} \mathrm{Cf}$. Garvie 1994, 217. 
in Ithaka, where he tells Penelope his story about all his dangerous adventures, repeating Calypso's words concerning the promise to make him immortal. The narrator reports ${ }^{71}$ his words as follows $(\mathrm{Od} .23 .333-7)$ :

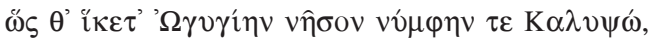

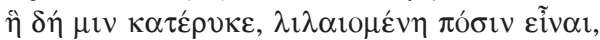

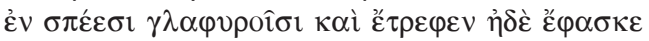

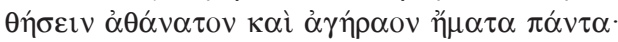

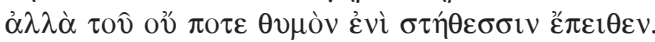

(how he came to the Ogygia and to the nymph Calypso who kept him there in her hollow caves, yearning that he should be her husband, and tendered him and said that she would make him immortal and ageless all his days; yet she could never persuade the heart in his breast. ${ }^{72}$ )

Again he manipulates the story totally omitting his early delight in the liaison with the nymph in order not to harm the wife. In both cases ${ }^{73}$ he tries to show that he was able to resist the temptation of being immortal, almost divine. He was all the time independent, heroic and persistent in striving to reach his aims.

Let us conclude with an ironic remark about Odysseus' immortality. Having spent seven years on Ogygia, night by night in Calypso's arms, ${ }^{74}$ every night he could confess, as the lover of Doris from Dioscorides' epigram $\left(A P 5.55^{75}\right)$,

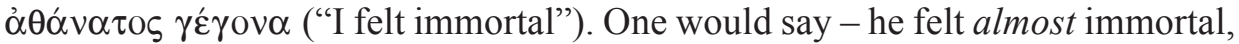
but not quite, to recall again Pelling's formulation. ${ }^{76}$ And that almost-but-not-quite was important. Apparently for Odysseus the almost was enough, Calypso expected the quite.

\section{BIBLIOGRAPHY}

Alden 1985: Alden, M. J. 1985. "The Rôle of Calypso in the Odyssey." Antike und Abendland 31: 97-107.

Anderson 1958: Anderson, W. S. 1958. "Calypso and Elysium." The Classical Journal 54, 2-11. Brügger 2016: Brügger, C. 2016. Homers Ilias. Gesamtkommentar, herausgegeben von A. Bierl und J. Latacz, Band IX 2: Kommentar von C. Brügger, Berlin.

\footnotetext{
${ }^{71}$ For the meaning of the indirect speech of Odysseus' report see de Jong 2001, 562.

${ }^{72}$ Transl. Murray 2004, 409.

${ }^{73}$ Mackie $(1995,91)$ rightly points out that in the hero's autobiographical storytelling "Odysseus' ability to construct deceptive narratives that resemble his experience" is crucial.

${ }^{74}$ This aspect of Odysseus' liaison is of special importance, as Giannini $(2014,62)$ rightly points out: "Anche la sessualità fa parte delle qualità di Odisseo. È significativo il semplice fatto che essa venga esplicitamente rilevata sia in rapporto a Circe sia in rapporto a Calipso. Tale tratto non è presente tra le caratteristiche di altri eroi, tranne Eracle, nel quale assume aspetti eccezionali."

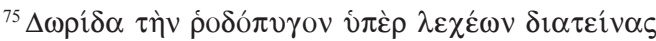

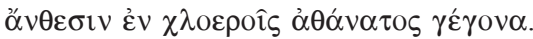

${ }^{76}$ Pelling 2014, 17.
} 
Buchan 2004: Buchan, M. 2004. The Limits of Heroism. Homer and the Ethics of Reading. Ann Arbor.

Cairns 2001: Cairns, D. L. 2001. Oxford Readings in Homer's Iliad. Oxford.

Cavafy 1992: Cavafy, C. P. 1992. Collected Poems. Transl. by E. Keeley, Ph. Sherrard. Princeton.

Crane 1988: Crane, G. 1988. Calypso: Backgrounds and Conventions in the Odyssey. Frankfurt am Main.

Currie 2016: Currie, B. 2016. Homer's Allusive Art. Oxford.

Danek 1998: Danek, Z. 1998. Epos und Zitat. Studien zu den Quellen der Odyssee. Wien.

Davies 1989: Davies, M. 1989. The Epic Cycle. Bristol.

De Jong 2001: de Jong, I. 2001. A Narratological commentary to the Odyssey. Cambridge.

Faulkner 2008: Faulkner, A. The Homeric Hymn to Aphrodite. Introduction, Text, and Commentary. Oxford:

Finkelberg 2015: Finkelberg, M. 2015. "Meta-Cyclic Epic and Homeric Poetry.” In The Greek Epic Cycle and Its Ancient Reception. Ed. by M. Fantuzzi and Ch. Tsagalis, 126-138. Cambridge.

Finley 1978: Finley, J. H. 1978. Homer's Odyssey. Cambridge and London.

Giannini 2014: Giannini, P. 2014. "Il viaggio dell'avventura: Odisseo." In Terra marique. Ricerche sul team del viaggio nella letteratura classica. Ed. by M. Capasso, 51-64. Lecce.

Garvie 1994: Garvie, A. F. Homer. Odyssey, Books VI-VIII. Cambridge.

Griffin 1977: Griffin, J. 1977. "The epic Cycle and the Uniqueness of Homer." JHS 97: 39-53.

Güntert 1919: Güntert, H. Kalypso. 1919. Bedeutungsgeschichtliche Untersuchungen auf dem Gebiet der indogermanischen Sprachen. Halle.

Hainsworth 1988. Hainsworth, J. B. 1988. "Commentary on Books V-VIII." In A Commentary on Homer's Odyssey, vol. I. Ed. by A. Heubeck, S. West, and J. B. Hainsworth, 249-385. Oxford.

Heubeck 1989: Heubeck, A. "Comemntary on Books IX-XII." In A Commentary on Homer's Odyssey, vol. II,. Ed. by A. Heubeck, A. Hoekstra, 3-116. Oxford.

Kozłowski 2015: Kozłowski, J. 2015. “Akadyjski epos o Gilgameszu i Odyseja.” Roczniki Humanistyczne 63, 5-22.

Kullmann 2015: Kullmann, W. 2015. "Motif and Source Research: Neoanalysis, Homer and Cyclic Epic.” In The Greek Epic Cycle and Its Ancient Reception. Ed. by M. Fantuzzi, Ch. Tsagalis, 108-125. Cambridge.

Lohmann 1988: Lohmann, D. 1988. Kalypso bei Homer und J. Joyce. Tübingen.

Mackie 1995: Mackie, H. 1995. "Song and Storytelling: An Odyssean Perspective." Poetica 5: 77-94.

Mitro 2008: Mitro, M. S. 2008. “«Mi disse: immortale / sarai, se rimani...» Calypso e Giovanni Pascoli." Maia 60, 6-14.

Most 2007: Most, G. W. 2007. Hesiod. The Shield, Catalogue of Women, Other Fragments. Cambridge (Mass.)-London.

Murray 1998: Murray, A. T. 1998. Homer. Odyssey. Books 1-12 Homer 1998. Cambridge (Mass.)London.

Murray 2001: Murray, A. T. 2001. Homer. Iliad. Books 13-24. Cambridge (Mass.)-London.

Murray 2004: Murray, A. T. 2004. Homer. Odyssey. Books 13-24. Cambridge (Mass.)-London.

Nagy 2010: Nagy, G. 2010. Homer the Preclassic. Berkeley-Los Angeles.

Pelling 2014: Pelling, Ch. 2014. Homer. In Twelve Voices from Greece and Rome. Ancient Ideas for Modern Times. Ed. by Ch. Pelling, M. Wyke. Oxford.

Ponatni 2013: Pontani F. 2013. "Speaking and Concealing. Calypso in the Eyes of Some (Ancient) Interpreters." Symbolae Osloenses 87, 30-60.

Pulleyn 2006: Pulleyn, S. 2006. "Homer's Religion: Philological Perspectives from Indo-European and Semitic." In Epic Interactions. Perspectives on Homer, Virgil, and Epic Tradition Presentes to Jasper Griffin by Former Pupils. Ed. by M. J. Clarke, B. G . F. Currie, and R. O. A. M. Lyne, 47-74.Oxford. 
Redfield 1994: Redfield, J. M. 1994. Nature and Culture in the Iliad. The Tragedy of Hector, Durham-London.

Richardson 2010. Richardson, N. 2010. Three Homeric Hymns. To Apollo, Hermes, and Aphrodite. Cambridge.

Rutherford 1991-1993. Ruttherford, R. B. 1991-1993. "From the Iliad to the Odyssey." BICS 38: $37-54$.

Sammons 2010: Sammons, B. 2010. The Art and Rhetoric of the Homeric Catalogue. Oxford.

Scodel 2009: Scodel, R. 2009. Listening to Homer: Tradition, Narrative and Audience. Michigan. Thornton 1970: Thornton, A. 1970. People and Themes in Homer's Odyssey. Dunedi.

Vernant 1996: Vernant, J.-P. 1996. "The Refusal of Odysseus." In Reading the Odyssey. Selected Interpretative Essays. Ed by. S. L. Schein, 185-9. Princeton.

Walcot 1991. Walcot, P. 1991. "The Homeric Hymn to Aphrodite. A Literary Appraisal." Greece and Rome 38: 137-155.

West 1997: West, M. L. 1997. The East Face of Helicon: West Asiatic Elements in Greek Poetry and Myth. Oxford.

West 2003: West, M. L. 2003. Homeric Hymns. Homeric Apocrypha. Lives of Homer. Cambridge (Mass.)-London.

West 2007: West, M. L. 2007. Indo-european Poetry and Myth. Oxford.

West 2013: West M. L. 2013. The Epic Cycle. A Commentary on the Lost Troy Epics. Oxford.

West 2014: West, M. L. 2014. The Making of the Odyssey. Oxford.

Wright-Mead 2011: Wright, T. and D. Mead. 2011. Oscar Wilde. The Women of Homer. London.

Zieliński 2014: Zieliński, K. 2014. Iliada i jej tradycja epicka. Studium z zakresu greckiej tradycji oralnej. Wrocław.

\section{CZY KALIPSO MOGŁA UCZYNIĆ ODYSEUSZA NIEŚMIERTELNYM?}

\section{Streszczenie}

Pobyt Odyseusza u Kalipso, stanowiący jeden z epizodów epickiej opowieści o powrocie bohatera do domu, przedstawiony został przez twórcę poematu jako rodzaj subtelnej psychologicznej gry bogini i śmiertelnika. Złudna oferta obdarzenia Odyseusza nieśmiertelnością, złożona mu przez Kalipso, jest jej desperackim wołaniem o wzajemność. Nieprzyjęcie oferty przez Odyseusza staje się dla niego z jednej strony warunkiem wypełnienia przeznaczonego mu losu heroicznego bohatera, który z determinacją niezłomnie dąży do wyznaczonego sobie celu, z drugiej otwiera mu możliwość budowania własnego wizerunku w kontaktach z innymi: zręczna manipulacja szczegółami dotyczącymi pobytu na Ogygii i relacji z boginią przyczynia się do autokreacji Odyseusza jako wiernego męża i człowieka, który jest w stanie oprzeć się niedostępnym innym ludziom pokusom. 